\title{
PERANCANGAN APLIKASI ANDROID AUGMENTED REALITY MEDIA PEMBELAJARAN DO'A SEHARI-HARI
}

\author{
Yudhi W. Arthana R. ${ }^{1}$, Asep Nurman Ismail ${ }^{2}$ \\ Program Studi Sistem Informasi \\ STMIK Indonesia Mandiri, Jl.Jakarta No.79 Bandung \\ Email: yudhie@stmik-im.ac.id ${ }^{1}$, asep.nurman12@gmail.com²
}

\begin{abstract}
ABSTRAK
Dalam proses pembelajaran do'a sehari-hari, pada umumnya para guru menerapkan metode membaca berulang-ulang melalui media cetak sebagai sarana pembelajaran yang kemudian dihafalkan oleh para peserta didik. Sehingga tidak menutup kemungkinan jika metode tersebut dapat menimbulkan kebosanan terhadap peserta didik yang pada umumnya merupakan golongan anak-anak, mengingat saat ini perkembangan teknologi telah mempengaruhi perilaku dan gaya belajar dari para peserta didik. Oleh karena itu perlu adanya inovasi dalam proses pembelajaran do'a sehari-hari yang efektif dan menarik yaitu dengan menggunakan teknologi augmented reality.

Teknologi augmented reality merupakan teknologi yang menggabungkan objek dua dan tiga dimensi kedalam suatu lingkungan nyata tiga dimensi lalu memproyeksikannya secara real-time. Metode yang digunakan untuk membangun aplikasi ini adalah metode pengembangan perangkat lunak model waterfall. Aplikasi ini mampu menampilkan suara dan animasi tiga dimensi dengan bantuan marker yang diintegrasikan dengan augmented reality yang diharapkan akan mampu membuat para peserta didik menjadi lebih tertarik dalam mempelajari do'a sehari-hari.
\end{abstract}

Kata Kunci : Do'a, Media Pembelajaran, Android, Augmented Reality

\section{PENDAHULUAN}

\subsection{Latar Belakang}

Do'a merupakan suatu rangkaian ibadah yang mempunyai keterkaitan dengan kesempurnaan iman dan islam seseorang. Oleh karena itu, berdo'a sangat dianjurkan oleh agama islam. Tetapi banyak yang menyangka bahwa berdo'a itu adalah suatu ibadah yang ringan, yang bisa dilakukan sesuka hati. Padahal berdo' a merupakan salah satu pendorong untuk mencapai harapan dan keinginan untuk hidup yang baik, teratur, dan terhindar dari segala hambatan serta gangguan. Menurut Imam Ghazali, pendidikan agama harus diajarkan kepada anak sedini mungkin, pertama kali dengan mendidik hati mereka dengan ilmu pengetahuan dan mendidik jiwanya dengan ibadah.

Proses pembelajaran do'a sehari-hari, pada umumnya para guru menerapkan metode membaca berulang-ulang melalui media cetak kemudian dihafalkan oleh perserta didik. Tidak menutup kemungkinan jika metode tersebut bisa menimbulkan 
kebosanan terhadap peserta didik yang pada umumnya merupakan golongan anak-anak, mengingat saat ini perkembangan teknologi telah mempengaruhi perilaku dan gaya belajar dari peserta didik tersebut. Banyak sekali aplikasi mengenai do'a sehari-hari yang bisa di download dengan smartphone, akan tetapi sering kali aplikasi yang tersedia masih berupa bentuk tulisan. Tentu saja hal ini dapat menurunkan minat belajar para peserta didik, mengingat isi dari aplikasi yang ada tidak bersifat interaktif dan menarik. Oleh karena itu diperlukanlah sebuah inovasi pada aplikasi pembelajaran do'a seharisehari berbasis android dengan menggunakan teknologi yang mampu menampilkan objek baik objek dua atau tiga dimensi dan suara kedalam sebuah aplikasi android. Terlebih lagi di dunia teknologi informasi saat ini telah menghadirkan sebuah teknologi yang mampu membuat pengguna bisa berinteraksi langsung dengan objek virtual. Teknologi tersebut dinamakan teknologi Augmented Reality.

Augmented Reality (AR) merupakan teknologi yang menggabungkan objek dua dan tiga dimensi ke dalam suatu lingkungan nyata tiga dimensi lalu memproyeksikannya secara real-time. Benda-benda maya menampilkan informasi berupa label maupun objek virtual yang hanya dapat dilihat menggunakan kamera telepon seluler. Tidak seperti realitas maya yang sepenuhnya menggantikan kenyataan, namun Augmented Reality hanya menambahkan atau melengkapi kenyataan. Pembelajaran melalui konsep Augmented Reality yang menyenangkan dan interaktif mampu meningkatkan minat belajar dari para peserta didik.

\subsection{Tujuan Penelitian}

Adapun tujuan dari penelitian ini adalah :

1. Memberikan sebuah media pembelajaran do'a sehari-hari pada aplikasi mobile berbasis android yang menarik dan tidak membosankan.

2. Menyediakan sebuah media pembelajaran do'a sehari-hari berbasis android dengan memanfaatkan teknologi Augmented Reality.

\section{LANDASAN TEORI}

Menurut Andre Kurniawan dkk. (2017 : 2) augmented reality atau dalam bahasa Indonesia diterjemahkan menjadi realitas tambahan adalah sebuah teknik yang menggabungkan benda maya dua dimensi maupun tiga dimensi ke dalam sebuah 
lingkup nyata tiga dimensi lalu memproyeksikan benda-benda maya tersebut dalam waktu nyata.

Sedangkan menurut R. Azuma (1997 : 357), augmented reality adalah teknologi yang menggabungkan benda maya dua dimensi atau tiga dimensi ke dalam sebuah lingkungan nyata tiga dimensi lalu memproyeksikan benda-benda maya tersebut ke dalam waktu nyata (real time). Tidak seperti virtual reality yang sepenuhnya menggantikan kenyataan, namun augmented reality hanya menambahkan atau melengkapi kenyataan. Paul migran dan Fumio Kishino mendefinisikan Milgram's Reality-Virtuality Continuum pada tahun 1994. Mereka mendeskripsikan sebuah kontinum yang membentang dari lingkungan nyata ke lingkungan virtual murni. Diantaranya terdapat augmented reality (lebih dekat ke lingkungan nyata) dan augmented virtuality (lebih dekat ke lingkungan virtual)

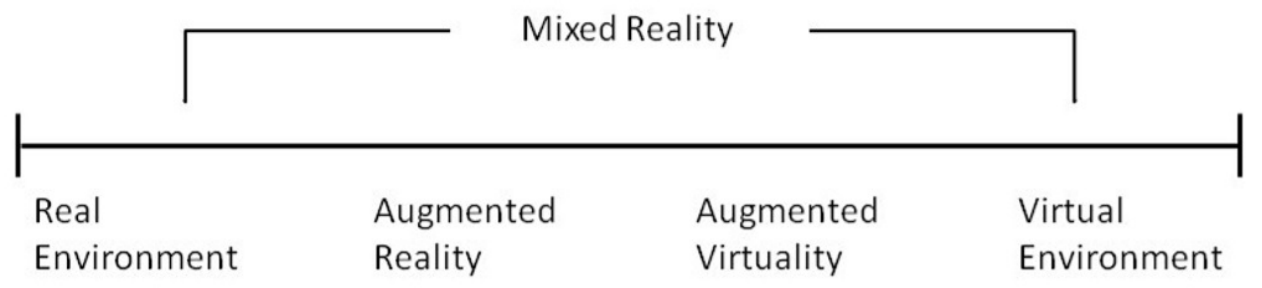

GAMBAR 1.1. Milgram's Reality-Virtuality Continuum (Siltanen, 2012 : 17).

Berdasarkan Bimber dan Raskar (2005 : 1), dilihat dari pengertiannya saja AR memang bersebrangan dengan VR, walaupun keduanya merupakan visualisasi virtual. Seperti contoh pada gambar 1.2, manusia, marker, dan ruangan, semuanya merupakan objek fisik. AR kemudian melapisi dunia fisik ini dengan informasi virtual berupa miniatur mobil tiga dimensi pada kertas marker. Jadi, AR berusaha menambah dunia fisik, sementara VR berusaha menggantikannya dengan menarik manusia ke dalam dunia virtual secara menyeluruh. 


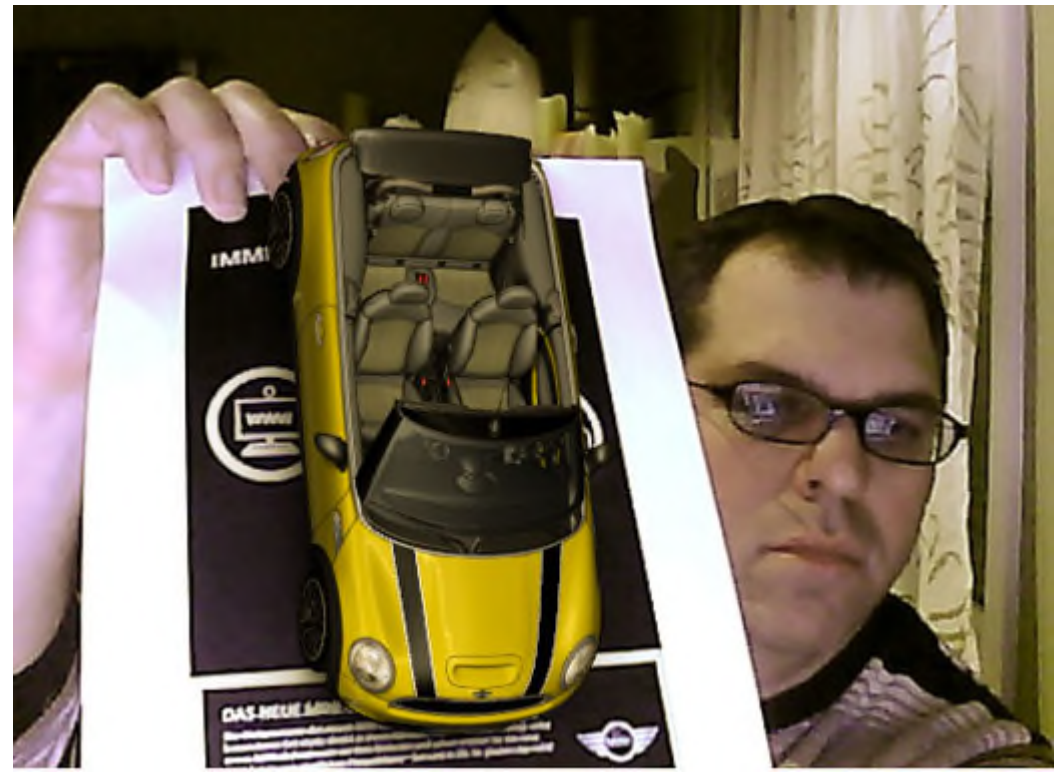

GAMBAR 1.2. Contoh Penggunaan Augmented Reality

Menurut Perey (2011 : 31), visinya di masa depan adalah bahwa setiap materi yang dicetak dimulai dari poster, paket yang dikirim, halaman dari koran, majalah atau buku dapat memberikan nilai bila dikombinasikan dengan kamera. Kombinasi dari sistem augmented reality (AR) dengan media cetak akan memberikan nilai dibandingkan dengan sesuatu yang dicetak saja atau konten digital saja.

Dengan bantuan teknologi augmented reality lingkungan nyata di sekitar kita akan dapat berinteraksi dalam bentuk digital atau virtual. Informasi-informasi tentag objek dan lingkungan di sekitar kita dapat ditambahkan kedalam sistem augmented reality yang kemudian informasi tersebut ditampilkan di atas layer dunia nyata secara real-time seolah-olah informasi tersebut nyata.

Menurut Saphiro dan Stockman (2000 : 574 ) pembuatan sistem augmented reality membutuhkan :

1. Model virtual dari objek untuk digabungkan dengan dunia nyata.

2. Korespondensi anatara dunia nyata dengan model virtual melalui kalibrasi secara real-time (waktu-nyata)

3. Tracking digunakan untuk menentukan sudut pandang pengguna terhadap dunia nyata

4. Real-time display yang digabungkan dengan citra asli dan juga grafik komputer yang dibuat berdasarkan model. 
5. Waktu respon terhadap gambar dan akurasi antar gambar dan grafik sangan mempengaruhi ke efektifan sistem.

\section{METODE PENELITIAN}

\subsection{Teknik Pengumpulan Data}

Adapun teknik pengumpulan data yang dilakukan penulis adalah :

1. Studi Lapangan meliputi :

a. Observasi langsung yaitu mengadakan pengamatan secara langsung bagaimana proses anak-anak dalam mempelajari do'a sehari-hari.

b. Wawancara yaitu teknik pengumpulan data dengan cara bertanya langsung kepada pihak-pihak yang berkaitan.

2. Studi Literatur

Pada tahap ini dilakukan studi literatur tentang informasi terkait, yakni melakukan studi kepustakaan terhadap referensi yang berkaitan dengan penelitian.

\subsection{Metode Perancangan Perangkat Lunak}

Metode perancangan yang digunakan dalam tugas akhir ini ialah menggunakan salah satu dari metode pengembangan perangkat lunak Software Development Life Cycle (SDLC) yaitu metode waterfall yang memiliki beberapa tahapan yaitu seperti pada gambar 1.3 .

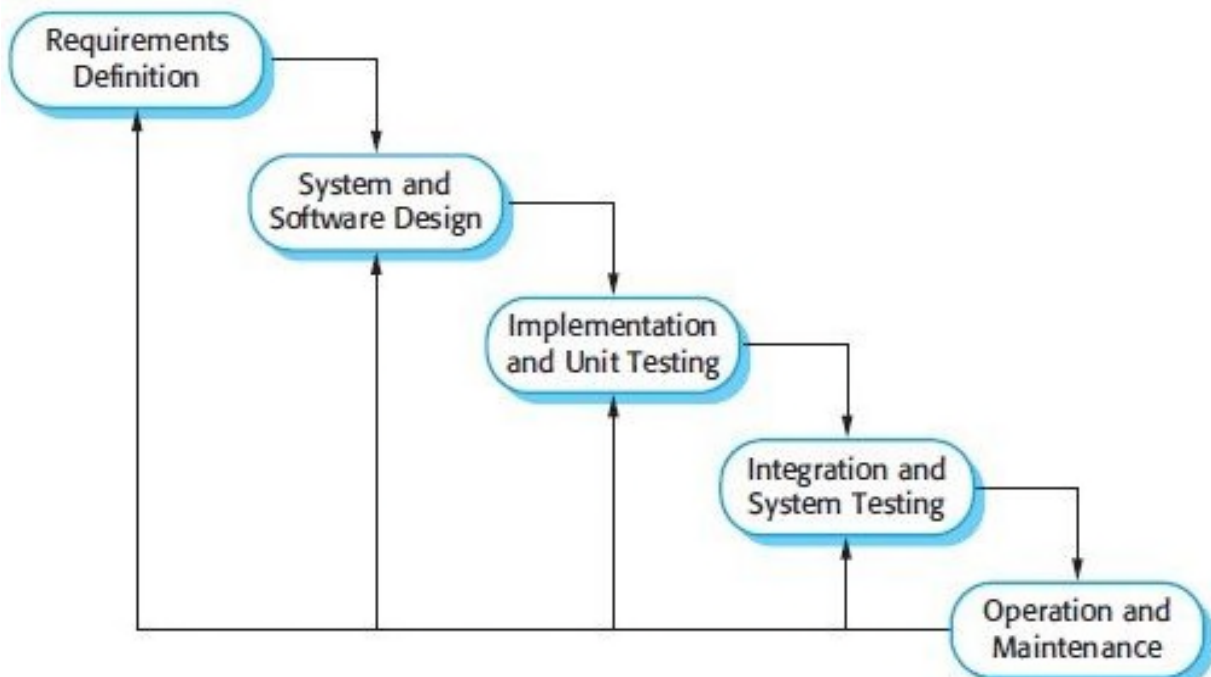

GAMBAR : 1.3 Model Waterfall (Ian Sommerville, $2011: 30$ ) 
Adapun penjelasan detail dari tahapan waterfall pada gambar 1.1 adalah sebagai berikut :

\section{Requirement Analysis and Definition}

Pada tahap ini proses pengumpulan kebutuhan dilakukan dengan cara menganalisis proses bisnis yang sedang berjalan dan hal-hal lainnya yang diperlukan dalam membangun aplikasi. Hal tersebut dilakukan untuk mengetahui perangkat lunak seperti apa yang akan dibuat serta kebutuhan akan perangkat keras juga supaya pengoperasian aplikasi bisa maksimal.

\section{System and Software Design}

Pada tahap ini dilakukan perancangan dari hasil analisis yang dilakukan di tahap sebelumnya. Pada tahap ini dilakukan pembuatan representasi desain perangkat lunak agar dapat diimplementasikan menjadi program pada tahap selanjutnya. Adapun dalam desain sistem perangkat lunak yaitu menggunakan model UML.

\section{Impelentation and Unit Testing}

Hasil dari representasi perangkat lunak pada tahap sebelumnya direalisasikan sebagai serangkaian program. Pada tahap ini dilakukan pembuatan aplikasi dengan menggunakan perangkat lunak Unity 3D dengan bahasa pemrograman C\# yang diimplementasikan pada perangkat mobile berbasis android.

\section{Integration and System Testing}

Pada tahap ini dilakukan pengujian aplikasi dengan cara menjalankan aplikasi, apakah aplikasi bisa berjalan dengan baik. Pengujian ini dilakukan dengan metode blackbox. Hal ini dilakukan untuk meminimalisir kesalahan (error) dan memastikan keluaran yang dihasilkan sesuai dengan apa yang diinginkan.

\section{Operation and Maintenance}

Setelah pengujian selesai, maka aplikasi dipasang dan digunakan. Pemeliharaan termasuk pembetulan kesalahan yang tidak ditemukan pada tahap sebelumnya.

\section{HASIL DAN PEMBAHASAN}

\subsection{Analisis Sistem}

Analisis ini bertujuan untuk mengidentifikasi permasalahan-permasalahan yang terdapat pada sistem yang akan dibangun. Bisa dikatakan analisis sistem merupakan penguraian dari suatu sistem untuk mengidentifikasi masalah-masalah atau hambatan- 
hambatan dalam sistem yang akan dibuat atau yang sedang berjalan. Sehingga akan dapat diusulkan kebutuhan-kebutuhan untuk memperbaikinya.

\subsubsection{Analisis Proses / Prosedur yang Sedang Berjalan}

Analisis terhadap sistem yang sedang berjalan bertujuan untuk mengetahui bagaimana cara kerja suatu sistem dan mengetahui masalah yang dihadapi sistem untuk dapat dijadikan sebagai landasan usulan perancangan. Tahap analisis diperlukan untuk mengetahui bagaimana proses pembelajaran do'a sehari-hari. Pada tahap perancangan ini, penulis menggambarkan sistem yang sedang berjalan dalam bentuk flowchart prosedur.

Berdasarkan hasil analisis yang dilakukan dengan metode wawancara, proses pembelajaran do'a sehari-hari dilakukan sebagai berikut :

Pengajar (guru) menyiapkan do'a yang akan dipelajari para peserta didik (murid). Biasanya para pengajar menyiapkan satu atau dua do'a pendek supaya proses penghafalan yang dilakukan para peserta didik (murid) lebih efektif. Sedangkan do'a yang dirasa panjang, dipelajari satu do'a dalam satu hari

1. Pengajar (Guru) menyampaikan do'a yang akan dipelajari oleh para peserta didik (murid) dengan cara menuliskan do'a tersebut ke dalam papan tulis supaya ditulis kembali oleh para peserta didik (murid). Metode ini dipercaya para pengajar bahwasanya pada saat para peserta didik menulis kembali tulisan yang ada di papan tulis, dipercaya dapat mempercepat proses pengafalan do'a tersebut.

2. Para peserta didik (murid) kemudian menulis kembali do'a yang disampaikan oleh pengajar (guru) ke dalam buku catatan masing-masing yang nantinya dijadikan pedoman (catatan) dalam proses penghafalan do'a tersebut. Adapun bagi para murid yang belum bisa menulis, para guru akan membimbing dengan cara melafalkan do'a tersebut yang nantinya diucapkan kembali oleh para murid.

3. Setelah para peserta didik sudah selesai menulis kembali do'a yang disampaikan, pengajar menjelaskan mengenai do'a tersebut kepada para peserta didik yang diharapkan mengerti akan maksud dari do'a yang telah dipelajari.

4. Kemudian para peserta didik biasanya diharuskan supaya bisa menghafal do'a yang telah dipelajari. Proses menghafal ini dilakukan dengan cara evaluasi baik sebelum berakhirnya proses pembelajaran ataupun sebelum memulai proses pembelajarann 
pada hari berikutnya. Jika dirasa belum hafal, para peserta didik akan disuruh menghafal kembali do'a tersebut.

Adapun penggambaran flowchart berdasarkan prosedur diatas digambarkan dalam gambar 4.1 berikut :

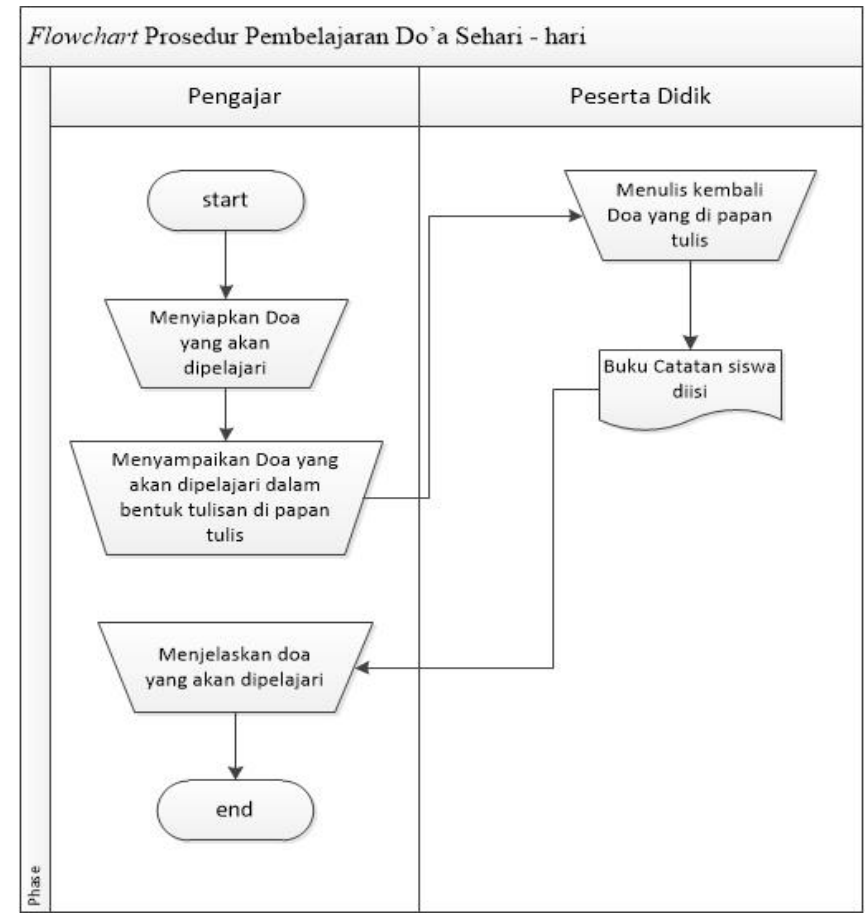

GAMBAR 4.1. Flowchart Prosedur / Proses Yang Sedang Berjalan.

\subsubsection{Analisis Masalah}

Analisis masalah merupakan langkah dimana langkah ini diperlukan untuk mengetahui permasalahan apa saja yang terjadi di dalam sistem yang sedang berjalan. Adapun identifikasi masalah pada penelitian ini adalah bagaimana cara meningkatkan kembali ketertarikan dan minat belajar pada anak-anak dalam mempelajari do'a seharihari dengan menggunakan konsep augmented reality.

\subsubsection{Analisis Sistem yang Diusulkan}

Analisis ini menjelaskan tentang kebutuhan atau kondisi yang harus dipenuhi dalam suatu sistem. Adapun sistem yang akan dibangun ini adalah sebuah sistem aplikasi augmentd reality sebagai media pembelajaran do'a sehari-hari berbasis android, dimana aplikasi ini dibuat sebagai sarana pembelajaran pada anak-anak dengan cara 
mendeteksi sebuah gambar dimana gambar tersebut berisikan do'a dengan bentuk text dan suara.

\subsubsection{Analisis Pengguna}

Agar penggunaan aplikasi dapat berjalan secara optimal dan sesuai dengan yang diharapkan, maka dibutuhkan kemampuan untuk menjalankan aplikasi. Dalam hal ini, kemampuan tersebut terutama adalah dapat mengoperasikan smartphone touchscreen dengan sistem operasi android. Akan tetapi batas minimal umur yang direkomendasikan yaitu lima tahun yang pendidikannya TK / PAUD.

\subsubsection{Analisis Marker}

Dalam pembuatan aplikasi augmented reality, marker berfungsi sebagai penanda. Secara default, marker memang menggunakan bingkai hitam dengan pola yang berada di bagian tengah. Akan tetapi marker juga bisa saja dapat berupa warna ataupun gambar. Pendeteksian marker dilakukan dengan cara mengenali bentuk dan pola yang terdapat pada marker. Dalam prosesnya, komputer akan mengenali posisi dan orientasi marker dan menciptakan dunia virtual 3D yaitu titik $(0,0,0)$ dan 3 sumbu yaitu $X, Y$ dan Z. Marker akan terekam oleh kamera secara real-time. Kemudian marker akan mengenali objek yang akan ditambahkan. Berikut ini merupakan alur sistem dari aplikasi augmented reality dengan metode marker.

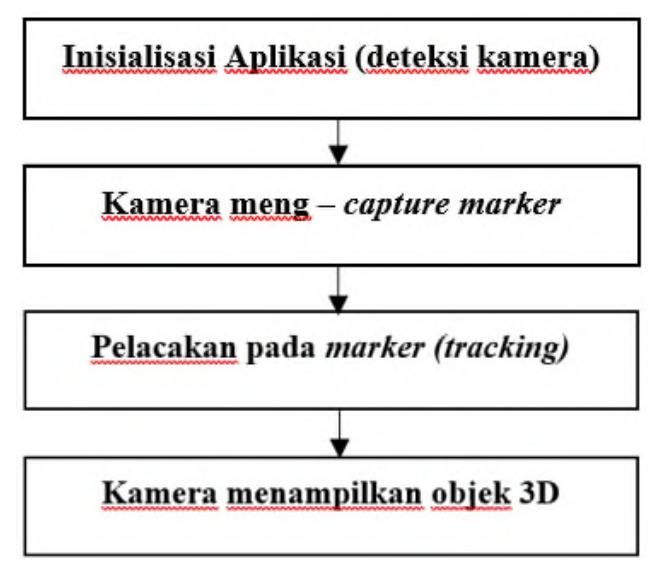

GAMBAR 4.2. Alur Sistem marker tracking pada sistem augmented reality 


\subsection{Desain Perangkat Lunak}

Desain atau perancangan merupakan tahap untuk memenuhi kebutuhan user mengenai gambaran yang jelas tentang perancangan dari sistem yang akan dibuat serta diimplementasikan. Adapun dalam tahap perancangan ini terdapat perancangan sistem dengan menggunakan notasi UML, perancangan marker, perancangan karakter, perancangan database, dan perancangan interface.

\subsubsection{Perancangan Sistem}

Dalam perancangan sistem perangkat lunak, penulis menggunakan model berorientasi objek dengan menggunakan notasi UML diantaranya use case diagram, activity diagram, class diagram, dan sequence diagram.

\subsubsection{Use Case Diagram}

Use case diagram merupakan gambaran aktifitas yang berjalan sesuai dengan kebutuhan. Use case diagram juga menggambarkan interaksi antara aktor dengan sistem yang akan dibangun guna mengetahui fungsi apa saja yang tersedia didalamnya.

Aktor dalam aplikasi ini, yaitu pengguna. Pengguna disini merupakan peserta didik baik dari kalangan anak-anak minimal 5 tahun ataupun dewasa. Adapun yang dapat dilakukan oleh pengguna antara lain yaitu melakukan scan marker, menjalankan animasi objek 3D, memperbesar ataupun memperkecil objek 3D dan melihat bacaan do'a. Berikut ini merupakan tabel deskripsi perancangan use case diagram yang digambarkan pada tabel 4.1 .

TABEL 4.1. Deskripsi Perancangan Use Case Diagram

\begin{tabular}{|l|l|l|}
\hline No & Notasi & \multicolumn{1}{|c|}{ Deskripsi } \\
\hline 1. & $\begin{array}{l}\text { Merupakan aktor yang dapat menjalankan } \\
\text { semua fitur aplikasi. }\end{array}$ \\
\hline 2. & Identifikasi Marker & $\begin{array}{l}\text { Merupakan fitur dimana pengguna dapat } \\
\text { melakukan scan terhadap marker yang } \\
\text { tersedia sehingga pengguna dapat } \\
\text { berinteraksi dengan objek 3D dari marker } \\
\text { tersebut. }\end{array}$ \\
\hline 3. & $\begin{array}{l}\text { Merupakan fitur dari aplikasi dimana } \\
\text { setelah pengguna melakukan proses scan } \\
\text { maka objek dan bacaan akan muncul } \\
\text { berdasarkan marker yang disediakan. Tiap- }\end{array}$ \\
\hline
\end{tabular}




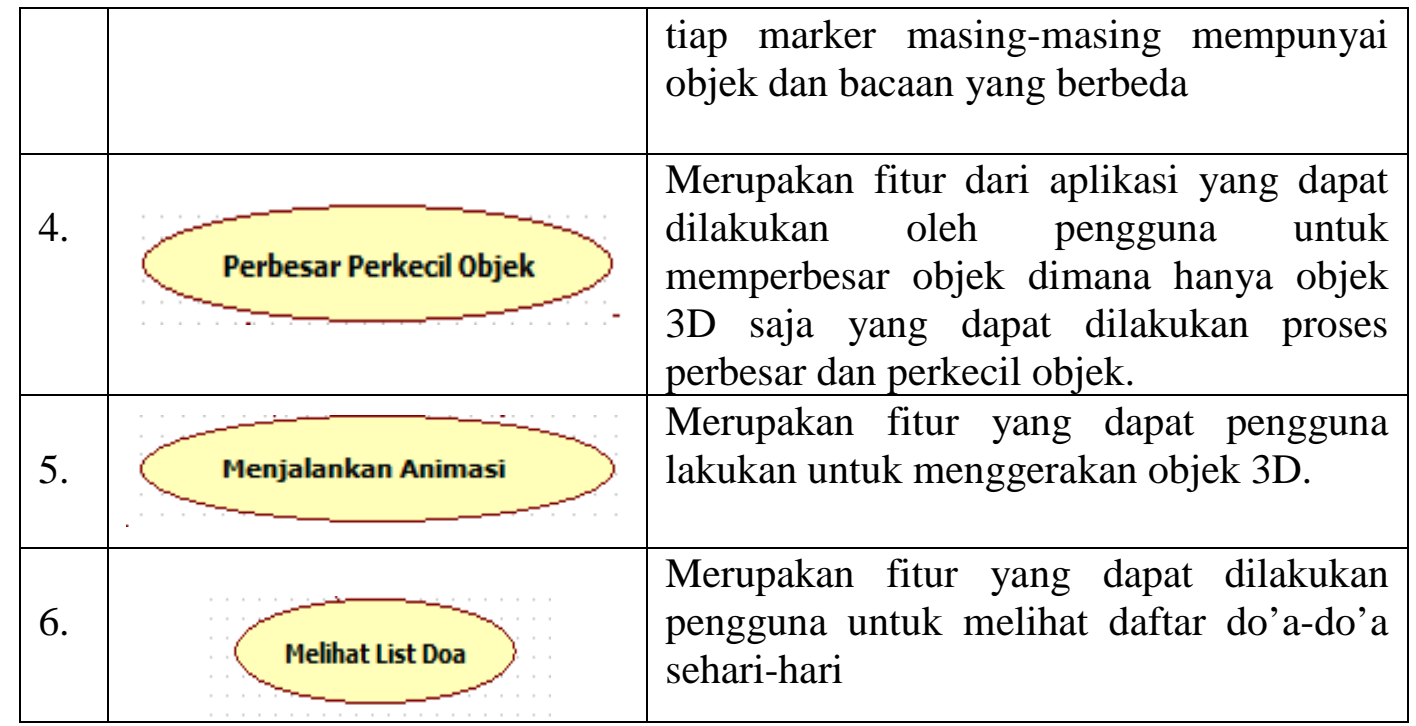

Adapun perancangan use case diagram dari aplikasi pembelajaran do'a seharihari ini digambarkan pada gambar 4.3 berikut ini :

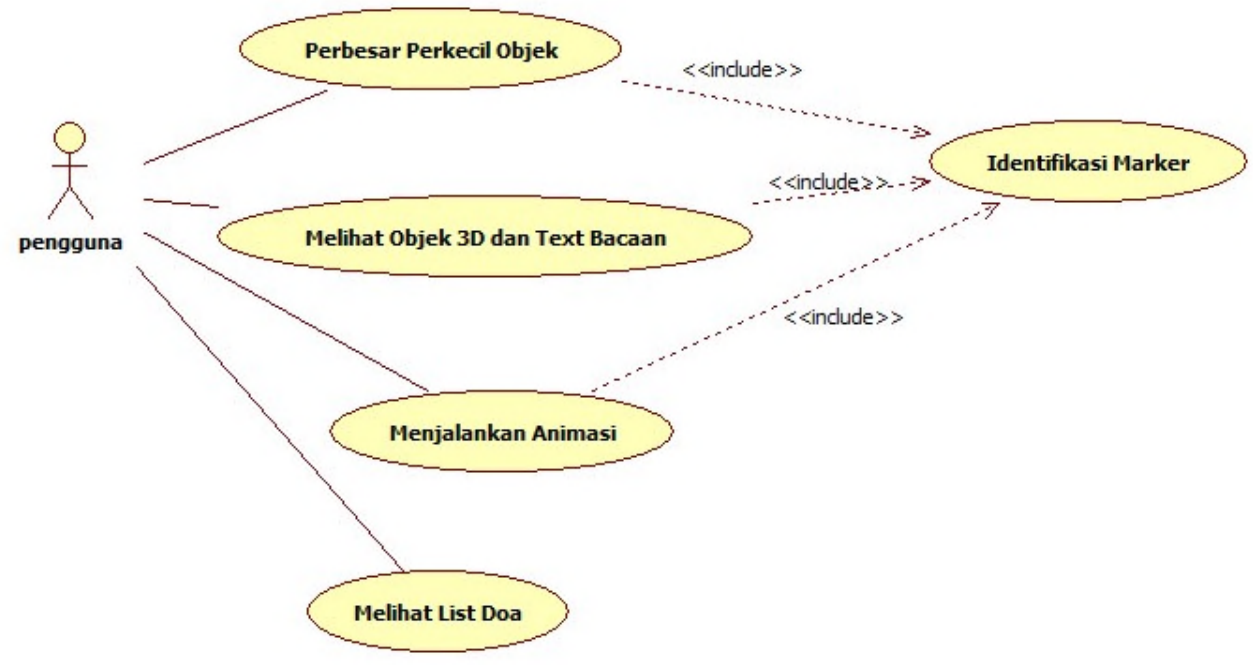

GAMBAR 4.3. Use Case Diagram Aplikasi Pembelajaran Do’a Sehari-hari.

\subsubsection{Activity Diagram}

Activity diagram digunakan untuk menggambarkan event-event yang terjadi di dalam use case diagram. Berdasarkan use case diagram aplikasi do'a sehari-hari pada gambar 4.3, maka dibuatkanlah activity diagram. 
1. Activity Diagram Identifikasi Marker (Scan Marker)

Menggambarkan bagaimana proses scan marker. Pengguna harus melakukan scan terlebih dahulu baru objek 3D pada marker akan muncul. Activity diagram scan marker digambarkan pada gambar 4.4

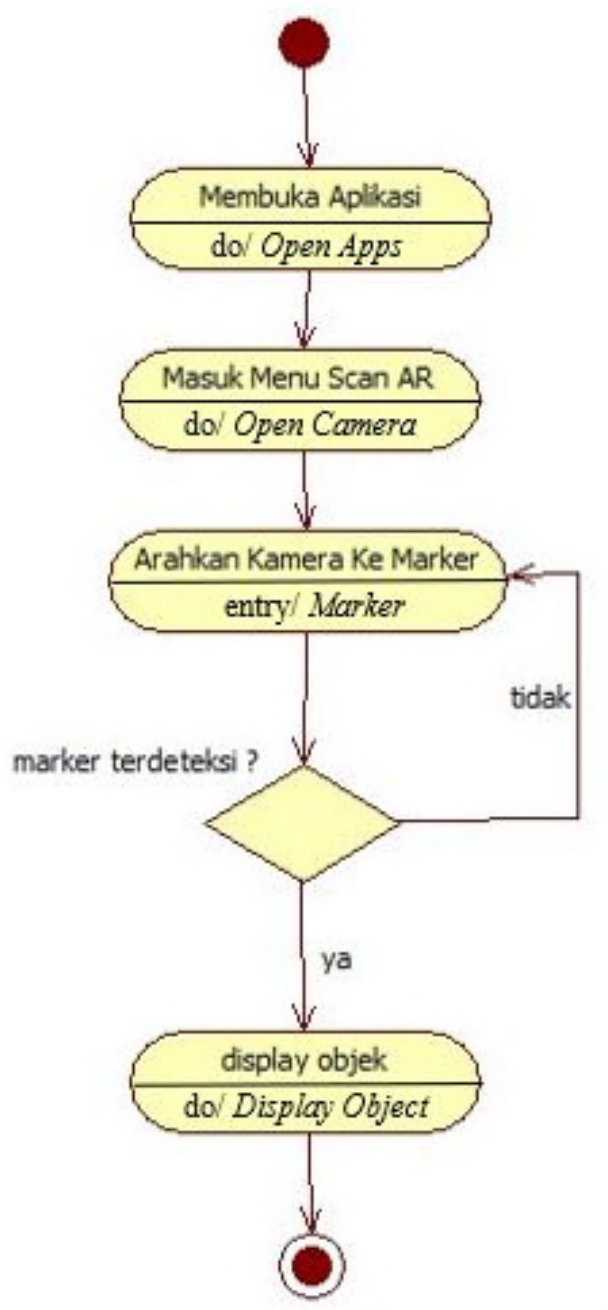

GAMBAR 4.4. Activity Diagram Identifikasi Marker (Scan Marker) pada Aplikasi Pembelajaran Do'a Sehari-hari 
2. Activity Diagram Menjalankan (Play) Animasi

Activity diagram pada gambar 4.5 menggambarkan proses dalam menjalankan animasi dari objek 3D pada marker.

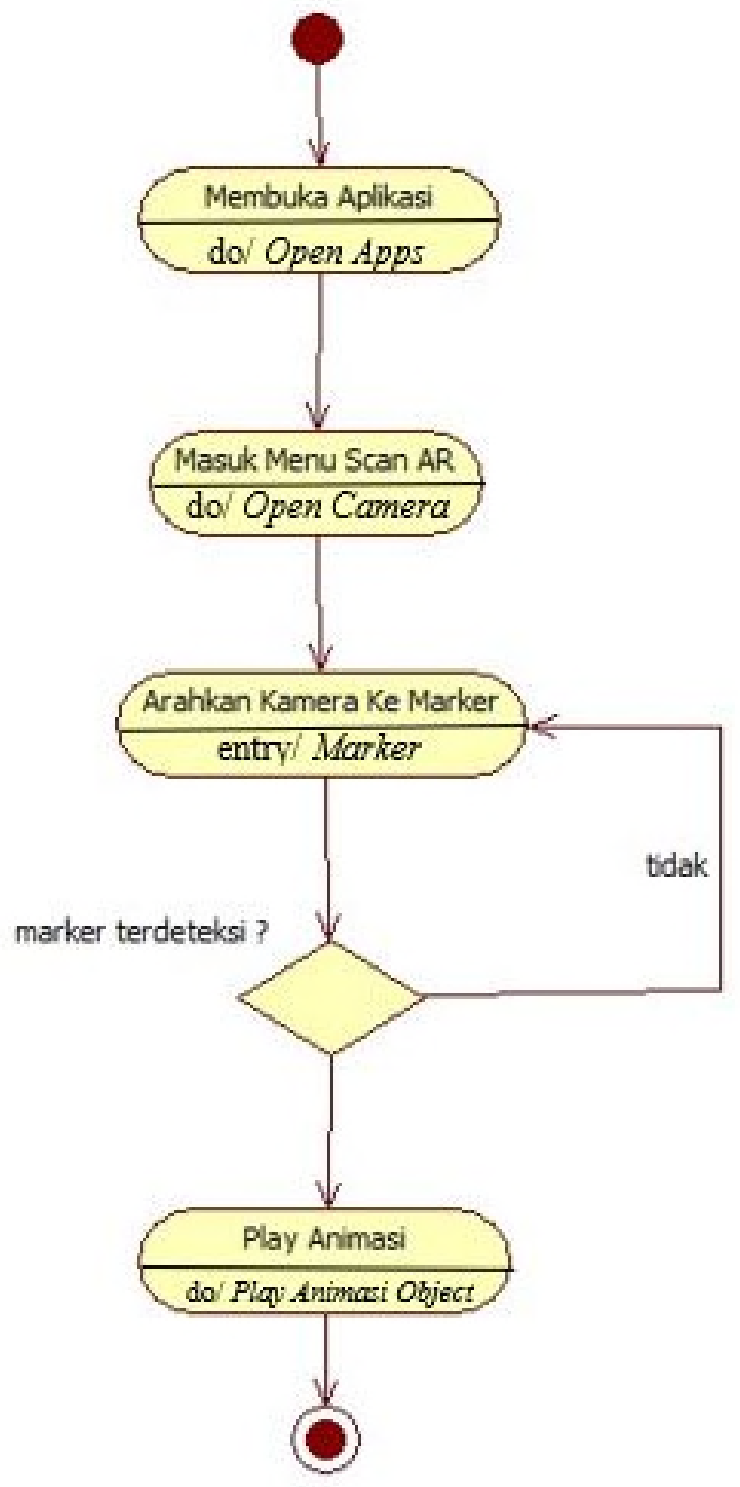

GAMBAR 4.5 Activity Diagram Menjalankan (Play) Animasi pada Aplikasi

Pembelajaran Do'a Sehari-hari 
3. Activity Diagram Perbesar Perkecil Objek

Activity diagram pada gambar 4.6 menggambarkan proses dalam memperbesar atau memperkecil objek 3D pada marker.

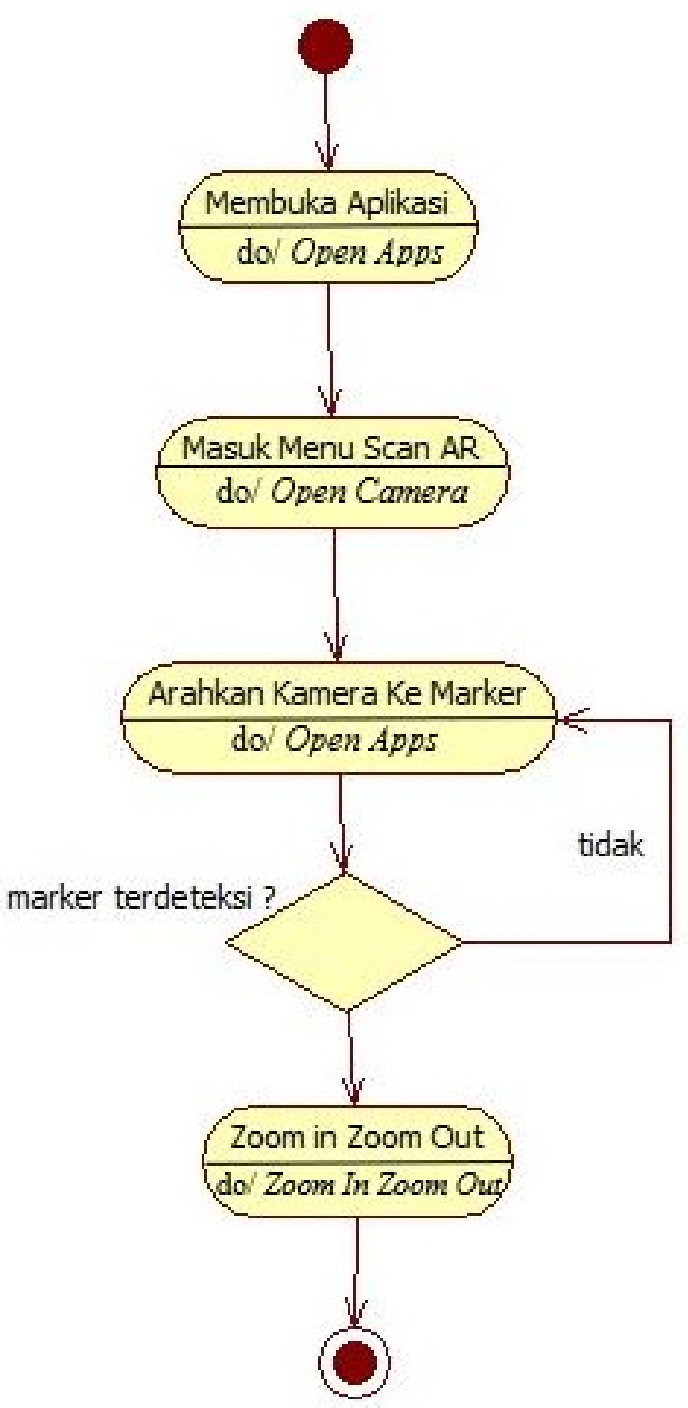

GAMBAR 4.6. Activity Diagram Perbesar Perkecil Objek 3D pada aplikasi do’a sehari-hari 
4. Activity Diagram Tampilkan Text Bacaan Do'a dan Objek 3D

Activity diagram pada gambar 4.7 menggambarkan proses dalam menampilkan text bacaan dan objek 3D pada marker.

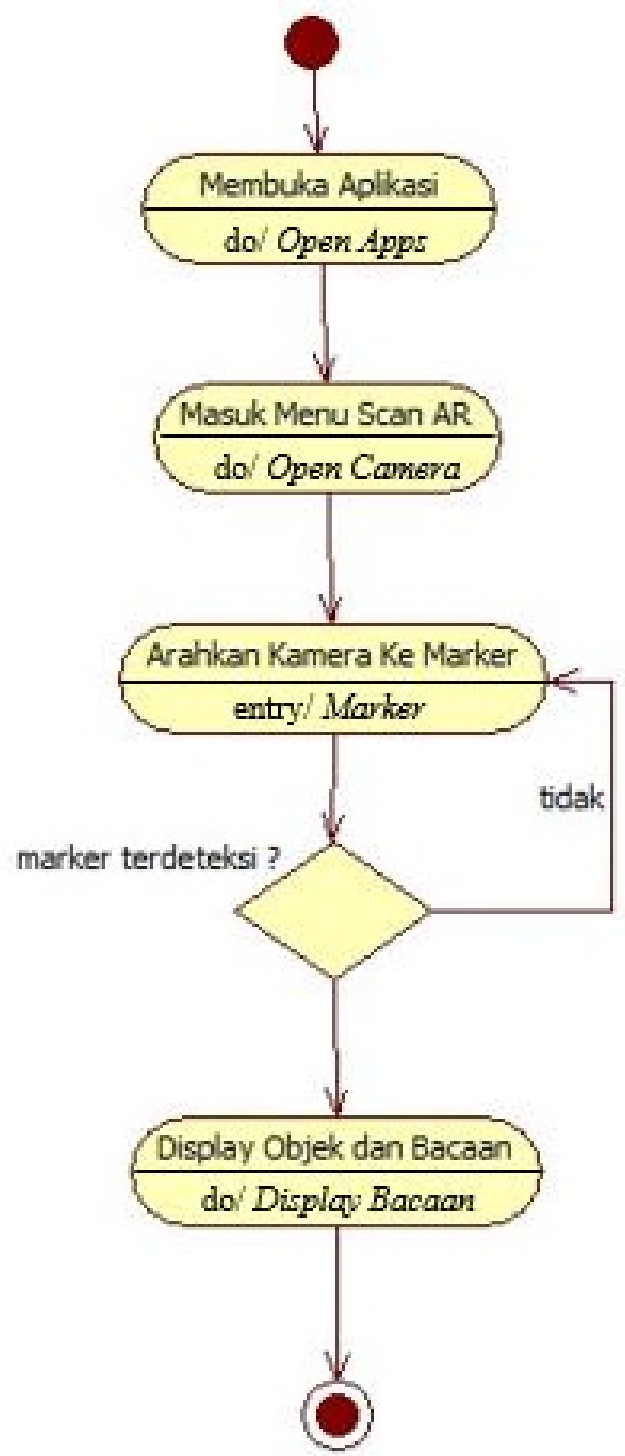

GAMBAR 4.7. Activity Diagram Tampilkan Text Bacaan dan Objek 3D 
5. Activity Diagram Menampilkan List Do'a

Activity diagram pada gambar 4.8 menggambarkan proses dalam menampilkan list do'a sehari-hari dalam bentuk list button yang disertai gambar.

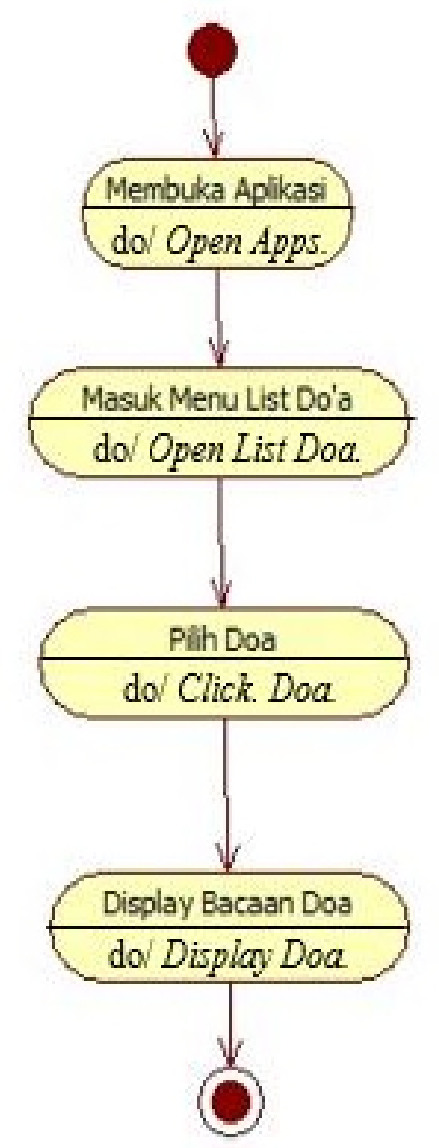

GAMBAR 4.8. Activity Diagram Tampilkan List Do'a

\subsubsection{Class Diagram}

Class diagram digunakan untuk menampilkan beberapa kelas yang ada dalam perangkat lunak yang akan dikembangkan. Class diagram menggambarkan struktur dan deskripsi beserta hubungan kelas yang satu dengan yang lainnya. Berikut ini merupakan class diagram dari aplikasi do'a sehari-hari digambarkan pada gambar 4.9. 


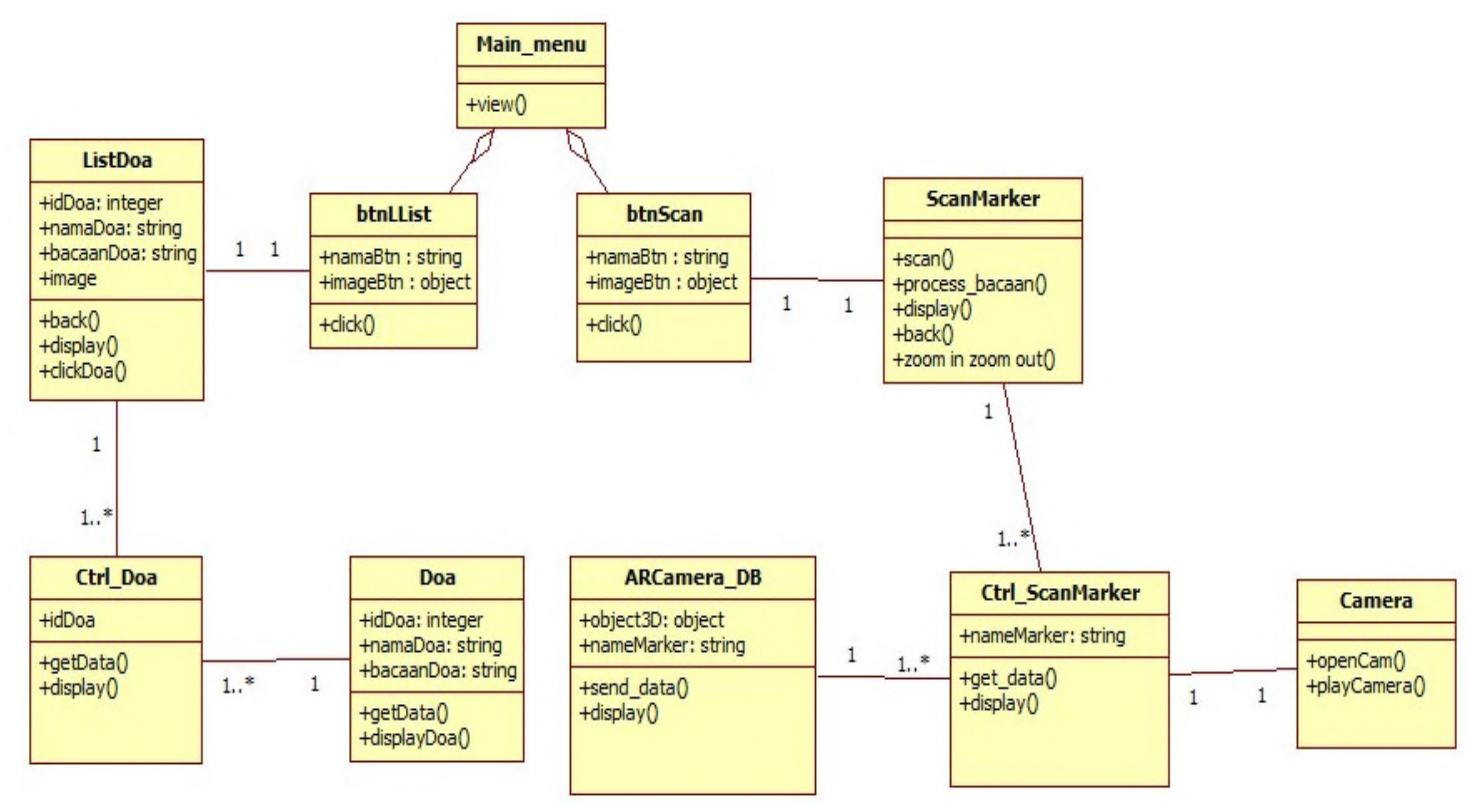

GAMBAR 4.9. Class Diagram Aplikasi Pembelajaran Do'a Sehari-hari

\subsubsection{Sequence Diagram}

Sequence diagram merupakan suatu diagram yang menggambarkan interaksi antara sebuah objek dalam urutan waktu. Kegunaanya yaitu untuk menunjukan rangkaian pesan yang dikirim antar objek juga interaksi antara objek yang terjadi pada titik tertentu dalam eksekusi sistem.

1. Sequence Diagram Scan Marker

Diagram ini mengambarkan urutan pesan yang ada dalam use case diagram scan marker pada aplikasi pembelajaran do'a sehari-hari. Berikut gambar 4.10 rancangan sequence diagram Scan Marker 


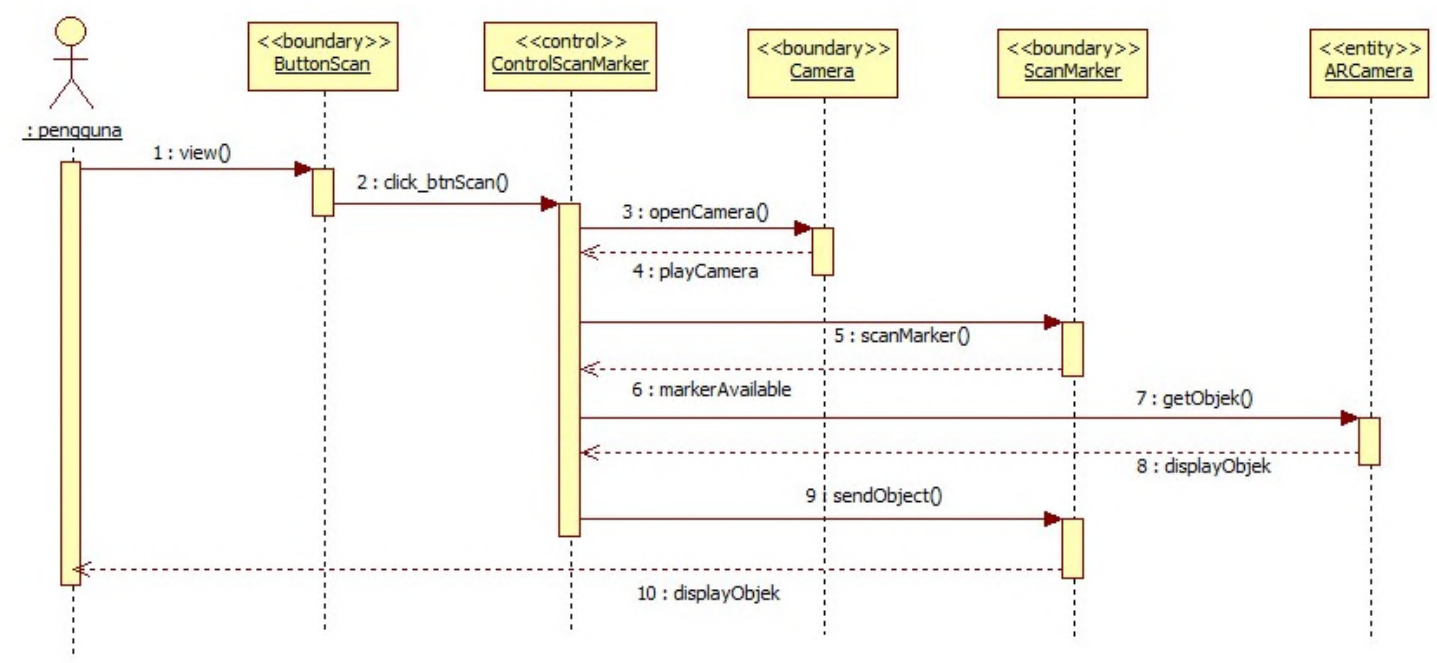

GAMBAR 4.10. Sequence Diagram Scan Marker

2. Sequence Diagram Perbesar Perkecil Objek

Diagram ini menggambarkan urutan pesan yang ada pada use case diagram perbesar perkecil objek pada aplikasi pembelajaran do'a sehari-hari. Sequence diagram ini menggambarkan proses dalam memperbeesar dan memperkecil objek 3D. Berikut gambar 4.11 rancangan sequence diagram pebesar perkecil objek

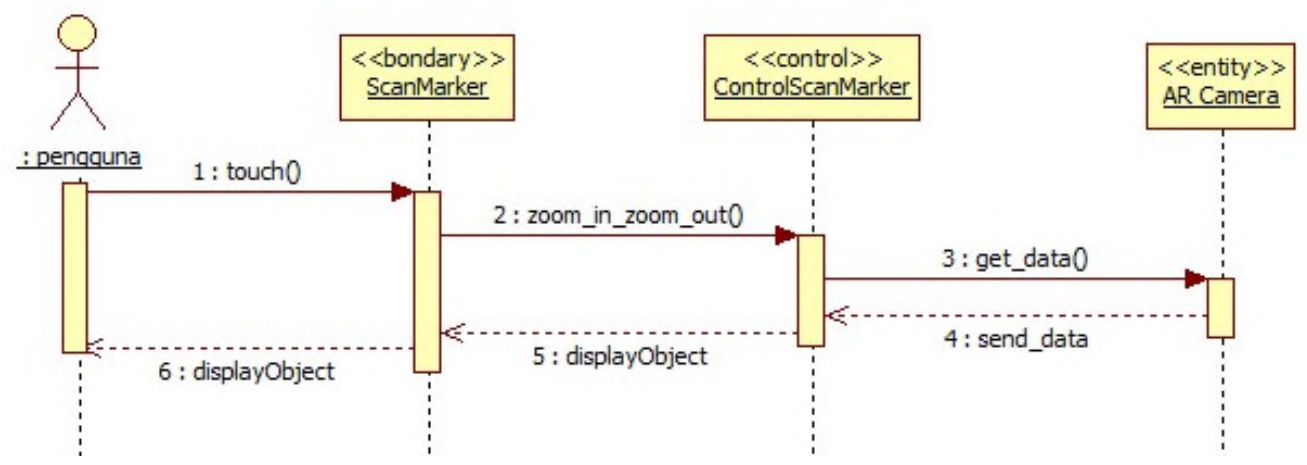

GAMBAR 4.11. Sequence Diagram Perbesar Perkecil Objek

3. Sequence Diagram Menampilkan Objek 3D dan Bacaan Do'a

Diagram ini menggambarkan urutan pesan yang ada pada use case diagram menampilkan objek 3D dan bacaan do'a pada aplikasi pembelajaran do'a seharihari. Sequence diagram ini menggambarkan proses dalam menampilkan objek 3D 
beserta bacaan do'a. Berikut gambar 4.12 rancangan sequence diagram menampilkan objek 3D dan bacaan do'a.

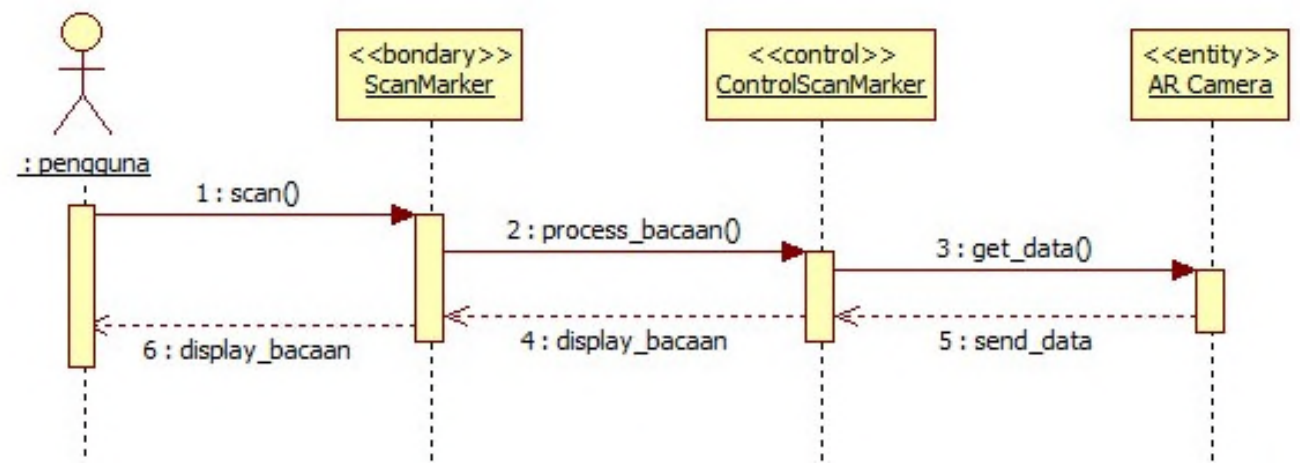

GAMBAR 4.12. Sequence Diagram Tampilkan Bacaan dan Objek 3D

\section{Sequence Diagram Play Animasi}

Diagram ini menggambarkan urutan pesan yang ada pada use case diagram play animasi pada aplikasi pembelajaran do'a sehari-hari. Sequence diagram ini menggambarkan proses dalam menjalankan animasi dari objek 3D pada marker. Berikut gambar 4.13 rancangan sequence diagram play animasi.

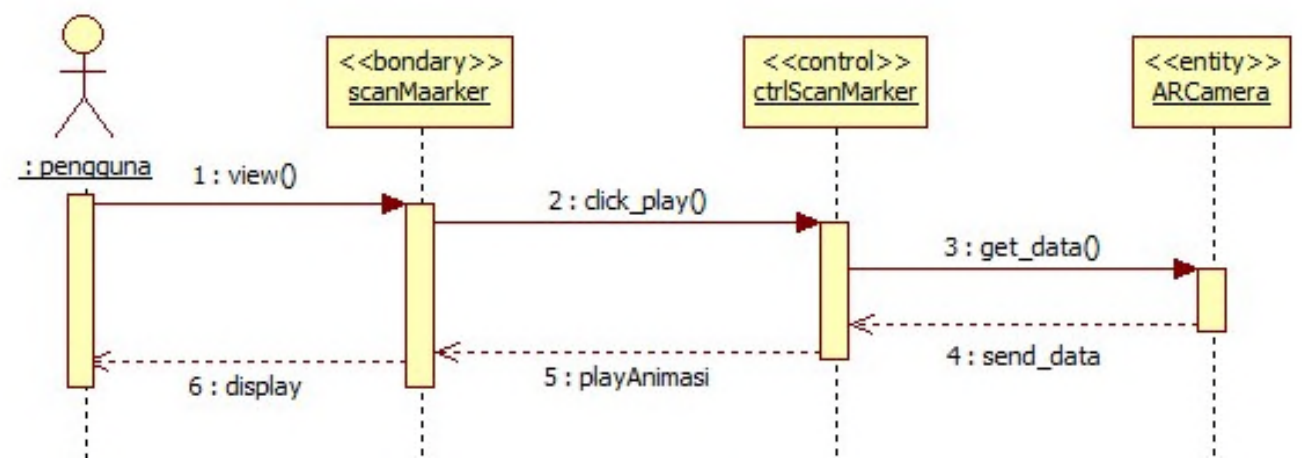

GAMBAR 4.13. Sequence Diagram Play Animasi

5. Sequence Diagram List Do'a

Diagram ini menggambarkan urutan pesan yang ada pada use case diagram menampilkan list do'a pada aplikasi pembelajaran do'a sehari-hari. Sequence diagram ini menggambarkan proses dalam menampilkan list do'a. Berikut gambar 4.14 rancangan sequence diagram menampilkan list do'a. 


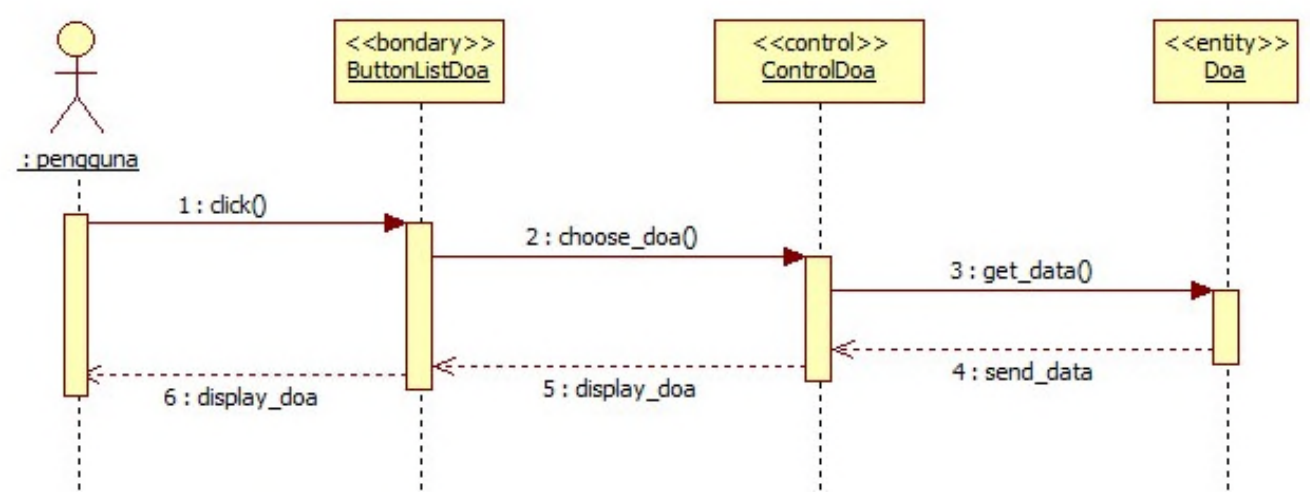

GAMBAR 4.14. Sequence Diagram Menampilkan List Do'a

\subsubsection{Perancangan Basis Data}

Dalam tahapan ini, penulis akan menjelaskan perancangan basis data (database) beserta tabel dari aplikasi yang akan dibangun yaitu aplikasi pembelajaran do'a seharihari. Dalam permodelan perancangan basis data menggunakan Entity Relationship Diagram (ERD). ERD menggambarkan relasi-relasi antar entitas. Berikut adalah gambar perancangan basis data aplikasi pembelajaran do'a sehari-hari :

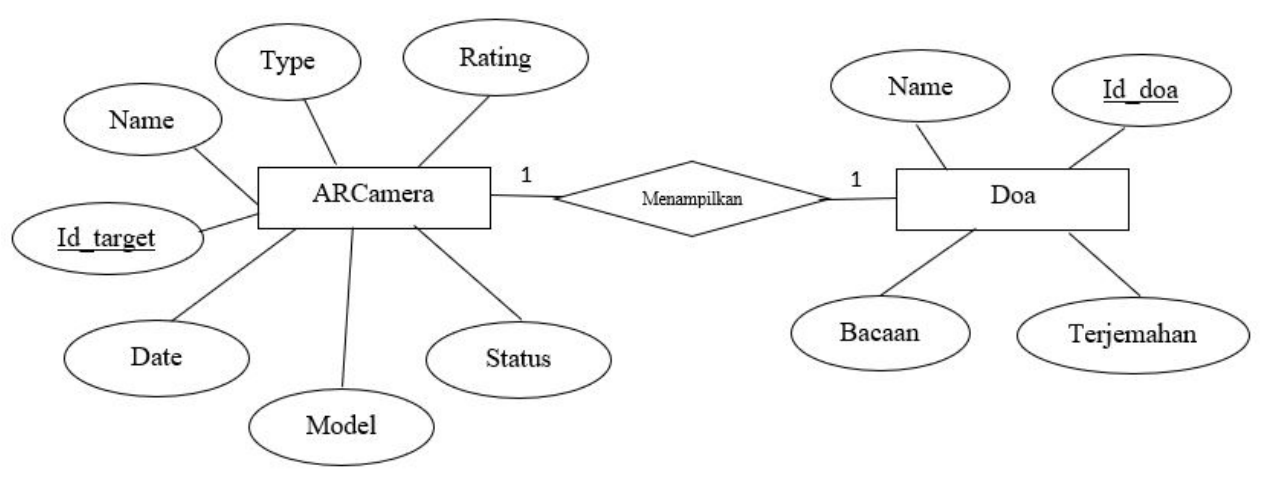

GAMBAR 4.15. Entity Relationship Diagram Aplikasi Pembelajaran Do'a Sehari-hari

\subsubsection{Perancangan Marker}

Marker merupakan komponen penting dalam aplikasi ini, karena metode marker based tracking merupakan tipe augmented reality yang mengenali marker dan mengidentifikasi pola marker tersebut untuk menambahkan suatu objek virtual ke lingkungan nyata. Adapun dalam pembuatannya, pertama adalah menentukan sampel gambar yang akan dijadikan marker. 


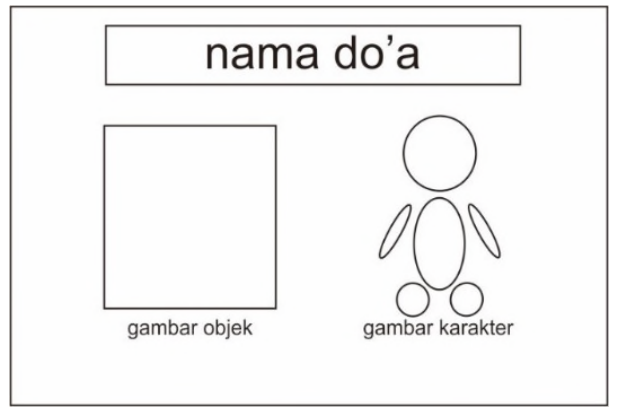

GAMBAR 4.16. Tampilan marker aplikasi do'a sehari-hari

\subsubsection{Perancangan Karakter}

Perancangan karakter adalah rancangan dari desain objek 3D yang akan diguanakan dalam aplikasi do’a sehari hari. Berikut ini adalah desain dari karakter yang digunakan.

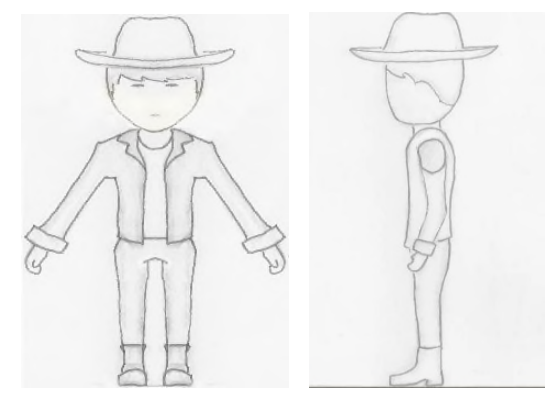

GAMBAR 4.17. Perancangan Desain Karakter Objek 3D

\subsubsection{Perancangan Antarmuka}

Perancangan Antarmuka merupakan rancangan dari antarmuka yang akan digunakan sebagai perantara user dengan perangkat lunak yang dikembangkan. Perancangan antarmuka dari aplikasi do'a sehari-hari ini dapat dilihat pada gambar 4.18 berikut :

1. Menu Utama (Main Menu)

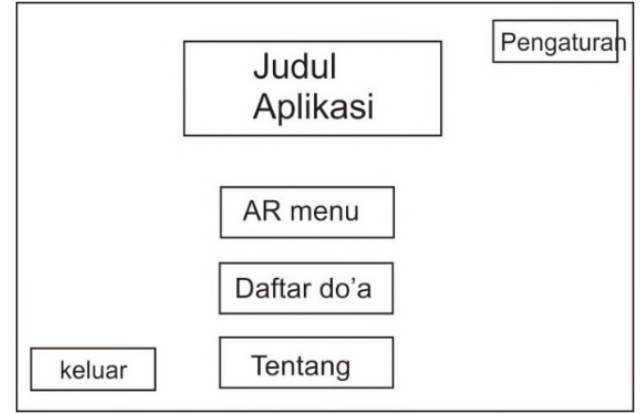

GAMBAR 4.18. Perancangan Tampilan Main Menu 
2. Menu Scan AR

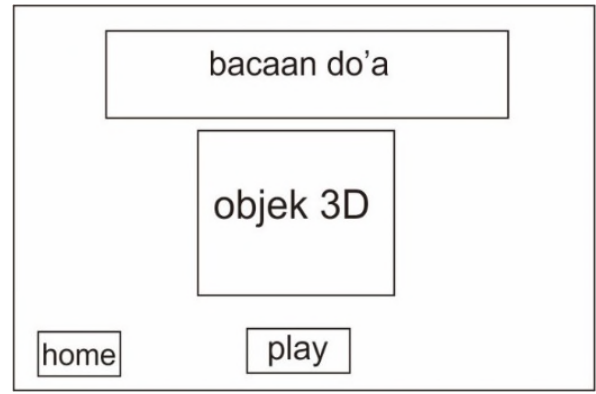

GAMBAR 4.19. Perancangan Tampilan Menu Scan AR

3. Menu Daftar Do'a (List Do'a)

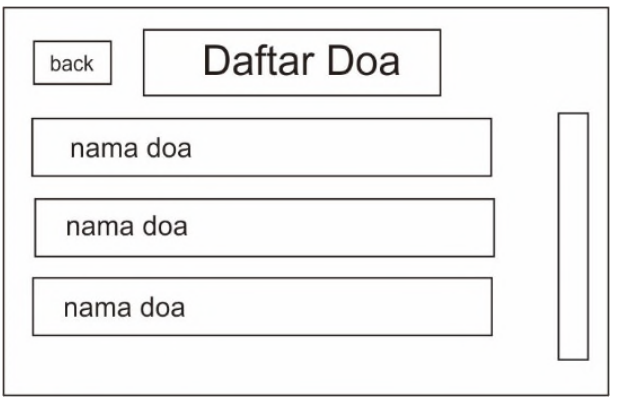

GAMBAR 4.19. Perancangan Tampilan Menu Daftar (list) Do’a

4. Isi Menu Daftar Do'a (berupa bacaan dari do'a yang dipilih)

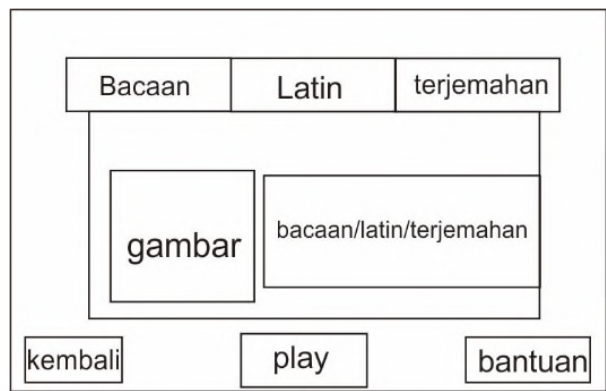

GAMBAR 4.20. Perancangan Tampilan Isi Menu List Do'a

\subsection{Implementasi}

Setelah aplikasi dianalisis dan dirancang secara rinci, maka selanjutnya menuju tahap implementasi. Implementasi merupakan tahap meletakan sistem sehingga siap untuk dioperasikan. Berikut ini adalah tahap implementasi aplikasi do’a sehari-hari 


\subsubsection{Implementasi Marker}

Implementasi marker merupakan proses pembuatan marker dimana marker tersebut akan dijadikan pengenal sehingga aplikasi akan menampilkan objek 3D berdasarkan marker yang akan di proses. Berikut ini adalah marker yang akan digunakan dalam aplikasi pembelajaran do'a sehari-hari yang digambarkan pada tabel 4.2

TABEL 4.2. Implementasi Marker

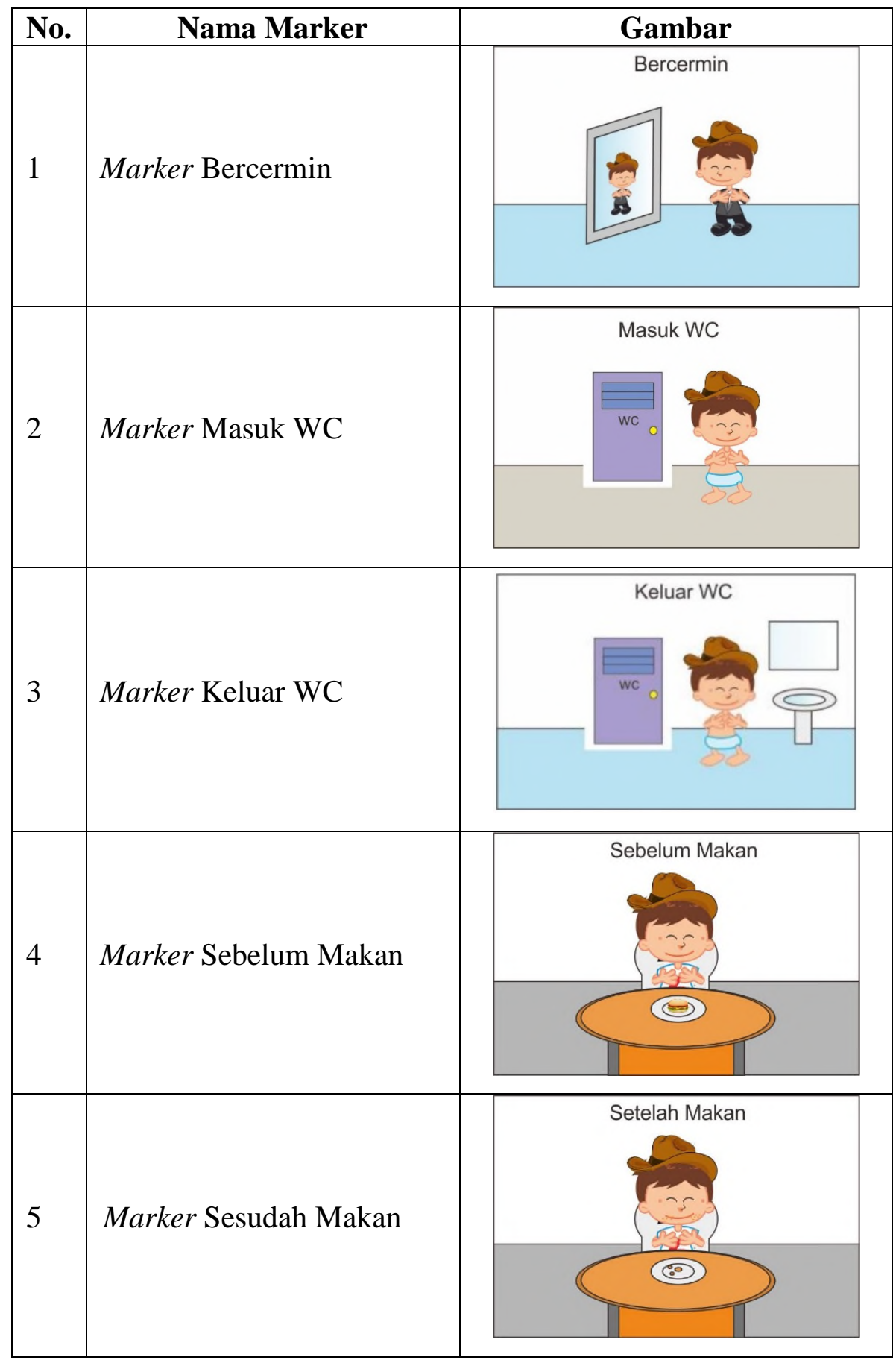




\begin{tabular}{|l|l|l|}
\hline 6 & Marker Sebelum Tidur & Sebelum Tidur \\
\hline 7 & Marker Bangun Tidur & \\
\hline
\end{tabular}

\subsubsection{Implementasi Model}

Implementasi model merupakan hal penting pada aplikasi augmented reality, dimana nantinya model (objek 3D) tersebut akan ditampilkan berdasarkan marker. Tabel 4.3 merupakan tampilan model (objek 3D) yang di desain dengan menggunakan blender.

TABEL 4.3. Implementasi Model 3D

\begin{tabular}{|l|l|c|}
\hline No. & \multicolumn{1}{|c|}{ Nama Model } & Gambar \\
\hline 1 & Model (Objek 3D) Karakter & \\
\hline 2 & Model Cermin & \\
\hline 3 & Model Meja Makan & \\
\hline
\end{tabular}




\begin{tabular}{|l|l|l|}
\hline 4 & Model Kamar Mandi & \\
\hline 5 & Model Kasur & \\
\hline
\end{tabular}

\subsubsection{Implementasi Aplikasi}

Berikut ini adalah implementasi aplikasi yang dibangun menggunakan bahasa C\# (CSharp) dan menggunakan game engine Unity 3D digambarkan pada gambar 4.21 sampai dengan gambar 4.24.

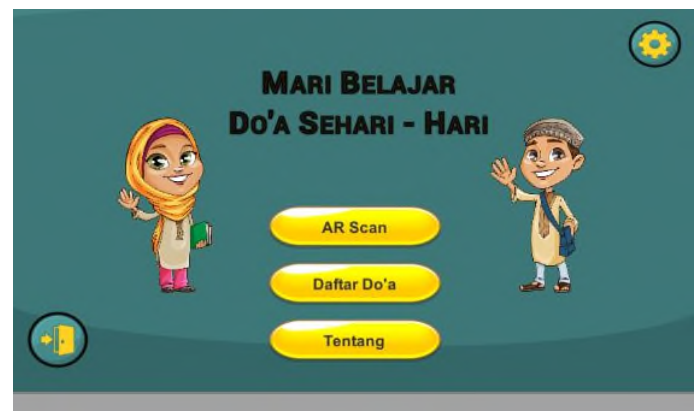

GAMBAR 4.21. Tampilan Main Menu

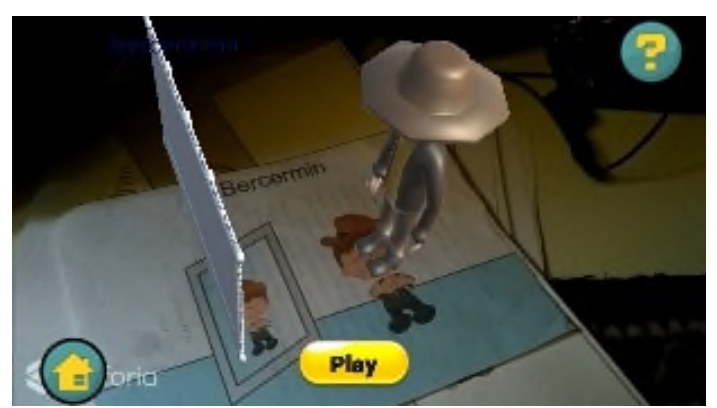

GAMBAR 4.22. Tampilan Menu Scan AR 


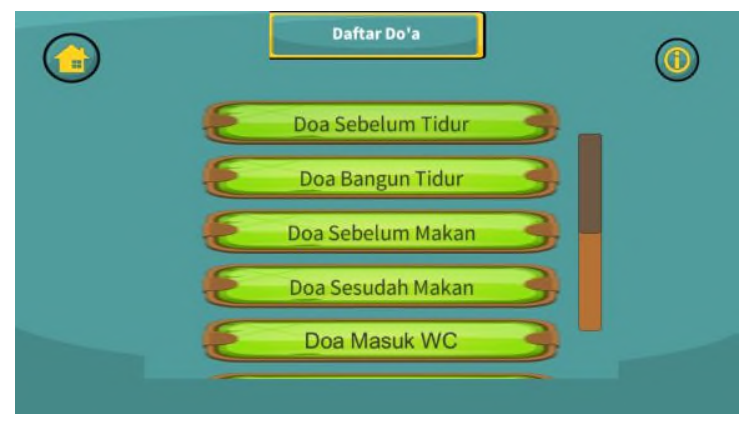

GAMBAR 4.23. Tampilan Menu Daftar Do'a

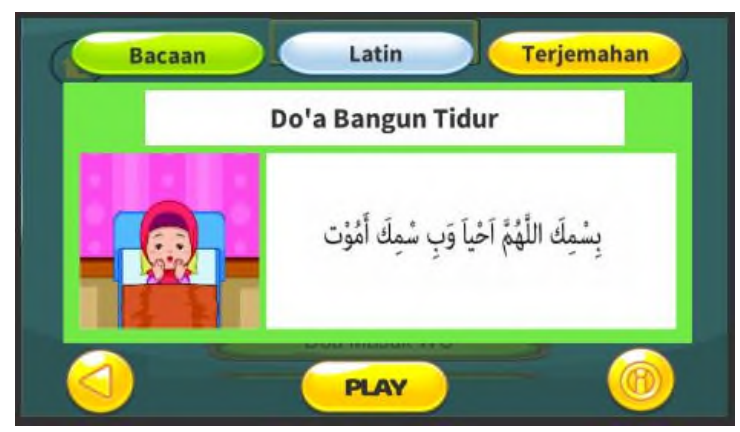

GAMBAR 4.24. Tampilan Menu Bacaan Daftar Do’a

\section{KESIMPULAN}

Kesimpulan yang diperoleh dari penulisan aplikasi android pembelajaran do'a sehari-hari menggunakan augmented reality ini adalah :

1. Menyediakan sebuah media pembelajaran do'a sehari-hari pada aplikasi mobile berbasis android dimana mampu menarik minat peserta didik dalam mempelajari do'a sehari-hari. karena dikemas dengan menggunakan teknologi augmented reality sebagai fitur utamanya.

2. Dengan adanya aplikasi do'a sehari-hari ini dapat membantu proses kegiatan belajar dikarenakan proses pembelajaran menggunakan teknologi augmented reality ini diharapkan akan mampu membuat para peserta didik menjadi lebih tertarik untuk mempelajari do'a sehari-hari.

\section{DAFTAR PUSTAKA}

Abdurahman, Hasan dan Riswaya, A H. Aplikasi Pinjaman Pembayaran Secara Kredit Pada Bank Yudha Bakti. Vol. 8. No. 2. hlm. 62. Desember,2014. 
A. K. Pamoedji . Maryuni. dan R. Sanjaya. 2017. Mudah Membuat Game Augmented Reality (AR) dan Virtual Reality (VR) dengan Unity 3D. Jakarta: PT. Elex Media Komputindo.

Azuma, Ronald T.1997. A Survey of Augmented Reality. Presence : Teleoperators and virtual environments 6 (4) : Hughes Research Laboratories. Malibu, CA , 1997.

A.S, Rosa dan Shalahuddin, M. 2016. Rekayasa Perangkat Lunak Terstruktur dan Berorientasi Objek. Bandung: Informatika.

Bimber, Oliver dan Raskar, Ramesh. 2005. Spatial Augmented Reality. A.K Peters. Amerika.

E Nur, Husda dan Wangdra, Yvonne. 2016. Pengantar Teknologi Informasi. Badause Media. Jakarta.

Harni, Kusniyati . Aplikasi Edukasi Budaya Toba Samosir Berbasis Android. Jurnal Teknik Informatika vol. 9 No.1, April 2016.

Hartono, Jogiyanto. 2010. Analisis dan Desain Sistem Informasi. Yogyakarta : Andi

Hodijah, Ade. 2015. Bikin Toko Online Di Android Dengan Webhost Gratis. Yogyakarta : Andi.

Jalianus, Nizwardi dan Ambiyar.(2016). Media dan Sumber Pembelajaran. Jakarta : K E N C A N A.

Nurseto, Tejo. 2011. Membuat Media Pembelajaran Yang Menarik, Yogyakarta : Jurnal Ekonomi \& pendidikan vol. 8 No. 1 April 2011.

Perey, Christine. 2011. Print and Publishing and The Future of Augmented Reality. PEREY Research and Consulting. Switzerland.

Ramadar, Pelsri. 2014. N.S Flartoolkit Flash Augmented Reality Alt Actionscript. Buku AR Online. Solo.

Saphiro, Linda dan Stockman, George. 2000. Computer Vision. Washington: Departement of Computer Science.

Siltanen, S. 2012. Theory and Applicarions of Marker-Based Augmented Reality. Finland : VTT.

Sommerville, Ian. 2011. Software Engineering (Rekayasa Perangkat Lunak). Jakarta: Erlangga. 
Susilana, Rudi dan Riyana, Cepi. 2009. Media Pembelajaran. Bandung : CV. Wacana Prima.

Sutoyo, T. 2009. Teori Pengolahan Citra Digital. Yogyakarta: Andi.

Syariati, Ali. 2002. Makna Doa. Pustaka Zahra : Jakarta.

Valino, James R. 1998. Interactive Augmented reality. Rochster, New York: University of Rochester. 